\title{
LEgislative REFORM AND EQUAL ACCESS TO THE JUSTICE SYSTEM: AN EXAMINATION OF ALBERTA'S NeW MinOR INJURY CAP IN THE CONTEXT OF SECTION 15 OF THE CANADIAN CHARTER OF RIGHTS AND FREEDOMS
}

\author{
BARbara BIL.I.INGSLeY*
}

This article surveys the provistons in Alberla's new legislation limiting recovery for motor veluicle accident victims suffering from minor injury. The anthor argues that the legislation effectively limits access to the justice system for a class of persons (those suffering minor injury) and this constitutes a violation of the equality guarantee in s. 15 of the Canadian Charter of Rights and Freedoms. She then outlines the practical impact of the legislation and employs the Law Test with reference to Nova Scotia (Workers' Compensation Board) v. Martin and Hernandez v. Palmer. These nvo cases dealt with situations where legislative distinctions benveen oypes of injury sufferers were struck down and upheld. respectively. The author emphasizes notions of fairness and access to the justice system in concluding that Alberta's legislation is an example of poor civil justice reform because it discourages and impedes deserving claims. The article concludes by urging a reconsideration of the legislation even in the absence of a constitutionat challenge.
Cet article passe en revuc les dispositions de la nouvelle legislation de l'Alberta Imitant le recouvrement pour tes victimes d'accidents automobile ayant subi wne lésion ligùre. $L$ 'auteur fait valoir que la legislation limite l'accels an système judiciaire pour une classe de personnes (notammen. celles ayant subi une lésion légère), ce qui constitue une infraction des Droits à l'égalité décrits à l'arricle I5 de la Charte canadienne des droits et libertes. Ensuile, elle donne les grandes lignes des répercussions pratiques de la législation ct a recours au Law Test en faisant refeirence aux causes Nova Scotia (Workers' Compensation Board) c. Martin et Hernandez c. Palmer. // s'agil de deux causes où les distinctions législatives entre les lypes de personnes lésées ont été respectivemen anmulées et accueillies. Dans sa conclusion. lauteur souligne les notions d'équité et d'accès au système judiciaire et elle déclare que la législation de l'Alberta est un exemple de mauvaise réforme de la justice civile puisqu'clle dissuade et fatt obstacle anx reclamations dignes d'imtérét.

\section{TABLE OF CONTENTS}

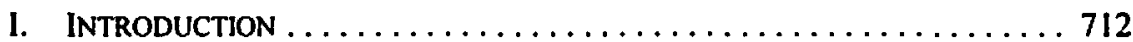

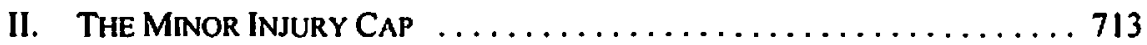
A. A SUMMARY OF THE LEGISLATIVE REFORMS

PERTAINIng to the Minor InJuRy CaP $\ldots \ldots \ldots \ldots \ldots \ldots 713$

B. IMPACT OF TIIE MINOR INJURY CAP AND

AsSOCIATEd Protocols . . .................. 718

III. EqUAL ACCESS TO JUSTICE - SECTION 15 OF THE CHARTER . . . . . 719

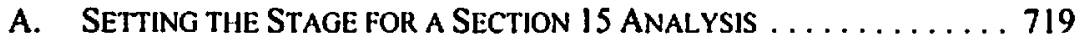

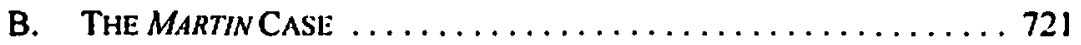

C. THE HERNANDEZ CASE . ................... 730

D. SOME FURTHER THOUGHTS ON THE EQUALITY ANALYSIS ..... 733

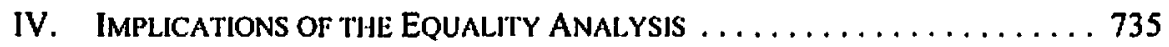

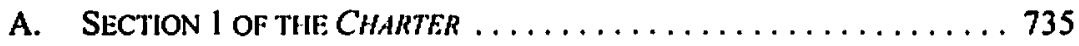

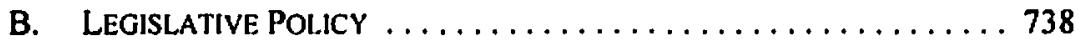

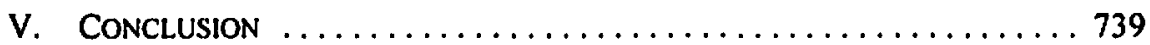

Assistant Professor, Faculty of Law, University of Albenta. My sincere thanks to Johnson Billingsley, Professor Peter Carver, Professor Joanna Harrington, Peter Michalyshyn, Q.C. and David Hicks for their comments and input on the issues raised in this article. 


\section{INTRODUCTION}

Will accident victims be denied access to the justice system?'

This crucial question is one of several queries raised and answered on the Government of Alberta's web page titled "Common Questions on Auto Insurance Reform." This access to justice issue arises because of the Alberta government's plan, as part of its overall automobile insurance reform (the Reform Package), ${ }^{2}$ to limit the amount of compensation recoverable by persons suffering minor injuries in a motor vehicle accident (the Minor Injury Cap). ${ }^{3}$ The government answers the question as follows:

Not at all. Even a person who has been diagnosed with what qualifies as a minor injury can disagree with the diagnosis and ask a court to review the decision. People with more scrious injuries can still go to court as they could under the old system for court-awarded compensation unrestricted by this act. ${ }^{4}$

Technically, this response is accurate. Viewed from a broader, less legalistic and less formalistic perspective, however, this answer is misleading.

The government's response presumes that access to the justice system exists as long as all people injured in motor vehicle accidents caused by the fault of another (MVA Injury Claimants) can place themselves before the courts to seek compensation from the party legally responsible for the accident (the Tortfeasor). In other words, the government reduces the notion of "access to the justice system" to a single, purely procedural concern, namely: does a mechanism exist whereby accident injury victims can bring their complaints before a court? A fulsome and meaningful understanding of "access to the justice system," however, must go beyond assessing the mere existence of court procedures and must also address the substantive utility and fairness of those measures. For example, consideration should be given 10 whether the available court proceedings are practical for all MVA Injury Claimants, whether the court procedures are fair and likely to yield meaningful results for all MVA Injury Claimants and whether judicial remedies are equally available to all MVA Injury Claimants.

See Question 17, "Common Questions on Auto Insurance Relorm," onlinc: Government of Alberta, <www.auloinsurance.gov.ab.ca/questions. $h$ tml>.

The Reform Package is authorized by the Insturance Amendment Act, 2003 (No. 2), S.A. 2003, c. 40 amending R.S.A. 2000, c. 1-3 [IAA], which was assented to on 4 December 2003. For the most part, this statute is enabling legislation, empowering the provincial cabinet to pass regulations on various automobile insurance matters. Many of the regulations authorized by the $I A A$ have now been passed and took clfect on I October 2004, including: the Automobile Accidem Insurance Benefits Amendment Regulation, Alta. Reg. 121/2004 [AAIBAR]; the Automoblle Insurance Premiums Regulation, Alta. Reg. 124/2004; the Diagnostic and Treatment Protocols Regulation, Alta. Reg. 122/2004 [DTR]; and the Minor Injun' Regulation, Alta. Reg. 123/2004 [MIR].

See Part II of this article for a detailed summary of the operation of the Minor Injury Cap in the context of Ule Reform Package. Because the regulations that impact on the Minor Injury Cap are new, varied and plentiful (ibid.), 1 have included in the footnotes of Part II complete quotes of the relevant portions of the regulations in question. My intention in doing so is to ensure that the regulatory provisions that I consider pertinent to the operation of the Minor Injury Cap are casily and instantly accessible to the reader. 
In this article, I contend that the Minor Injury Cap denies some MVA Injury Claimants "access to the justice system," when that phrase is given an appropriate, fulsome definition. More specifically, I argue that, in the light of recent constitutional jurisprudence, the Minor Injury Cap violates the Canadian Charter of Rights and Freedoms' guarantee of equal benefit of the law. In short, my position is that, because the Minor Injury Cap fails to provide meaningful access to the justice system for all MVA Injury Claimants, this legislative reform constitutes both bad law (in constitutional terms) and bad legislative policy. ${ }^{6}$

I begin this discussion by briefly explaining the operation of the Minor Injury Cap in the context of the Reform Package as a whole. Next, I offer an analysis of the Minor Injury Cap under s. 15 of the Charter, emphasizing case law involving facts comparable to the Minor Injury Cap. This discussion is not intended to be a summary or a critique of existing s. 15 Charter jurisprudence, but rather serves the more modest goal of simply evaluating the Minor Injury Cap in light of the prevailing constitutional equality test. Lastly, I offer some comments on the implications of this equality analysis of the Minor Injury Cap, both in terms of automobile insurance reform in particular and in terms of civil justice reform in general.

\section{I1. THE MinoR IN.JURy CAP}

\section{A. A Summary of the legislative Reforms Pertaining TO THE MinOR INJURY CAP}

As already noted, the Minor Injury Cap is part of the Alberta government's recent overhaul of the province's automobile insurance system. ${ }^{7}$ Neither the legislation, the

3. Section 15 of the Canadian Charter of Rights and Freedoms, Part I of the Constitution Acl 1982, being Schedule B to the Canada ACt 1982 (U.K.), 1982, c. 11 [Charter], provides as follows:

(1) Every individual is equal before and under the law and has the right to the equal protection and equal benefit of the law without discrimination and, in particular, without discrimination based on race, national or ethnic origin, colour, religion, sex, age or mental or physical disability.

(2) Subsection (1) does not preclude any law, program or activity that has as its object the amelioration of conditions of disadvantaged individuals or groups including those that are disadvantaged because of race, national or ethnic origin. colour. religion, sex. agge or mental or physical disability.

- The restriction of the present discussion to $\mathrm{s}$. 15 of the Charter should not be interpreted as a comment on other possible constitutional clıallenges regarding the Reform Package or the Minor Injury Cap. I do not claim that $s$. 15 is necessarily the only basis upon which these legislative provisions iniglt be challenged. I do, however, contend that the equality issue is onc of the most obvious and serious constitutional problems raised by the Minor Injury Cap. Further, my decision to focus this critique on the Minor Injury Cap is not intended to be an implicit endorsement or rejection of any other feature of the Reform Package. A thorough examination of the other reform features is simply beyond the scope of this article. I do, however, refer to some of these features to the extent that they impact on my consideration of the Minor Injury Cap.

1. The authorizing provision for the Minor Injury Cap is found in s. 650.1 of the IAA. supra note 2, which provides as follows:

(1) In this section, "minor injury" means an injury as defined or othenwise described by regulation as a minor injury.

(2) In an accident claim, the amount recoverable as damages for non-pecuniary loss of the plaintiff for a minor injury must be calculated or otherwise determined in accordance with the regulations.

(3) The Lieutenant Governor in Council may make regulations

(a) defining minor injury or othenvise describing what constitutes a minor injury:

(b) providing for the classification of or categories of minor injuries; 
government Web sites nor the government press releases offer any objective specific to the Minor Injury Cap; however, the stated purpose of the Reform Package as a whole is "to provide consumers with access to fair and affordable insurance." Closely linked to the Minor Injury Cap are new treatment protocols for motor vehicle accident injury victims. ${ }^{9}$ The stated purpose of the treatment protocols is to "promote quick recovery through fast and effective treatment."

The Minor Injury Cap limits every individual who suffers minor injury in a motor vehicle accident (a Minor Injury Claimant) to a maximum recovery of $\$ 4,000$ in non-pecuniary damages from the Tortfeasor." Compensation for pain and suffering of a Minor Injury Claimant is thereby "capped" at $\$ 4,000$. The Minor Injury Claimant can, however, still

(c) providing for the assessment of injuries, including, without limitation, regulations establishing or adopting guidelines, best practices or other methods for assessing whether an injury is or is nol a minor injury:

(d) governing damages, including the amounts of or limits on damages, for non-pecuniary loss for minor injuries;

(c) governing deductible amounts or limits and the application of those amounts or limits in respect of damages for non-pecuniary loss for minor injuries;

(f) providing for or otherwise setting out circunstances under which a minor injury to which this section would otherwise apply is exempt from the operation of this section;

(g) governing the application of this section in respect of injuries arising out of an accident where:

(i) it is unclear as to whether or not this section applies to those injuries, or

(ii) the injuries consist of a combination of minor injuries to which this section applies and injuries to which this section docs not apply;

(h) establishing and governing a system or process under which a person or a committec, panel or other body may seview any injury to a person and give an opinion as to whether or not the injury is a minor injury:

(i) providing for the appointment or designation of persons ot of members of committees. panels or other bodies for the purposes of a system or process established under clause (h);

(j) governing the payment of any fees, levies and other assessments in respect of a system or process established under clause (h), including, without limitation, regulations respecting

(i) the amount of the fees, levies or other assessments or the manner in which and by whom any of those amounts are to be determined, and

(ii) by whom and to whom the fees, levies or other assessments are to be paid:

(k) governing any transitional matter concerning the application of this section in respect of matters dealt with under this section;

(1) providing for any matter that the Lieutenant Governor in Council considers advisable for carrying out the purpose and intent of this section.

Taken from a statement by Alberta Finance Minister Patricia Nelson, "Legislation introduced to provide Albertans with fair and affordable auto insurance" (24 November 2003), online: Government of Alberta, News Release <www.gov.ab.ca/acn/200311//5526.html>. The Finance Minister elsewhere described the reform package as follows: "These sweeping reforms are truly a 'made-in-Alberta" solution... We have developed a system that provides drivers with access to fair, affordablc insurance that includes the privale sector to ensure Alberlans benefit from a competitive market." (Taken from Government of Alberta. News Release, "New auto insurance system unveiled" (27 May 2004), online: Albenta Finance <mww.finance.gov.ab.ca/whatsnew/ncwsrel/2004/0527.html>.

DTR, supra note 2.

"Treatment Process for Minor Injuries," onlinc: Government of Alberta < www.autoinsurance.gov.ab.cal process.himl> [emphasis in original].

This limitation is set out in $s .6$ of the MIR, supra note 2, which provides that "the total amount recoverable as damages for non-pecuniary loss for all minor injuries sustained by a claimant as a result of an accident shall not exceed $\$ 4000$." 
recover from the Tortfeasor full compensation for any out-of-pocket expenses arising from the injury. ${ }^{12}$

If a MVA Injury Claimant suffers multiple injuries, the new system requires each injury to be individually assessed and characterized as either minor or non-minor. ${ }^{13}$ The maximum amount of general damages recoverable for all the minor injuries remains at $\$ 4,000$ in total. Non-pecuniary damages for non-minor injuries are not capped, even if such injuries occur in conjunction with minor injuries. ${ }^{14}$

According to the regulations, a "minor injury" has two characteristics. First, it must be either a muscle injury (a strain), a tendon or ligament injury (a sprain), or a whiplashassociated disorder (a WAD) that does not include a spinal fracture or dislocation or "objective, demonstrable, definable and clinically relevant neurological signs." "Second, the injury must not result in "serious impairment" - that is, a "physical or cognitive function"

Although there may be legal arguments over the precise nature of the losses that should be encompassed by the term "non-pecuniary damages," the intention of the Alberta government is apparently to continue to allow all motor vehicle accident victims to fully recover from the Tortfeasor damages for "lost income, future income, medical and rehabilitation costs, and any other out-of-pocket expenses." ("Overview of Reforms," online: Government of Alberta, <iwnw.autoinsurance.gov.ab.ca/ overview.html>.)

11 See s. 2 of the $M I R$, supra note 2, which provides as follows:

If a claimant sustains more than one injury as a result of an accident, each injury must be assessed separately to determine whether the injury is or is not a minor injury.

See s. 7 of the $M I R$, ibid., which provides that:

(1) In this section, 'non-minor injury' means an injury other than a minor injury.

(2) If a claimant sustains one or more minor injuries and one or more non-minor injuries as a result of an accident, the assessment of damages for non-pecuniary loss for all injuries sustained by the claimant is subject to the following rules:

(a) if the non-minor injury or injuries, when assessed separately from the minor injury or injuries, would result in an award for non-pecuniary loss of not more than $\$ 4000$, the total amount recoverable as damages for non-pecuniary loss for all injuries sustained by the claimant shall not exceed $\$ 4000$ :

(b) if the non-minor injury or injuries, when assessed separately from the minor injury or injuries, would result in an award for non-pecuniary loss of more than $\$ 4000$, the total amount recoverable as damages for non-pecuniary loss for all injuries sustained by the claimant shall be calculated as the total of

(i) the amount of damages assessed for non-pecuniary loss for the non-minor injury or injuries, and

(ii) subject to section 6, the amount of damages assessed for non-pecuniary loss for the minor injury or injuries.

I(h) "minor injury", in respect of an accident, means

(i) a sprain,

(ii) a strain, or

(iii) a WAD injury

caused by that accident that does not zesult in a serious impairment:

(k) "sprain" means an injury to one or more tendons or ligaments, or to both:

(I) "strain" means an injury to one or more muscles:

(n) "WAD injury" means a whiplash-associated disorder other than one that exhibits one or both of the following:

(i) objective, demonstrable, definable and clinically relevant neurological signs:

(ii) a fracture to or a dislocation of the spine. 
impairment that results in a "substantial inability" to perform "essential tasks" of employment, education or normal daily living and that is "expected not to improve substantially." to a functional impairment will be considered to result in serious impairment. ${ }^{17}$ In summary, for purposes of the Minor Injury Cap, a "minor injury" is a soft tissue injury that does not cause long-term functional impairment.

Of particular relevance to the operation of the Minor Injury Cap is the manner in which a soft tissue injury is diagnosed and treated. The Reform Package includes a series of diagnostic and treatment protocols for sprains, strains and WAD injuries caused by a motor vehicle accident. ${ }^{18}$ Unless these protocols are followed, the law presumes that a sprain, strain or WAD injury is a "minor injury" and is therefore subject to the Minor Injury Cap even if the injury results in serious impairment. The onus is on the injured party to prove either that a reasonable excuse exists for not having followed the protocols or that the soft tissue injury would have resulted in serious impairment even if the protocols had been followed. ${ }^{19}$

While a detailed discussion of these protocols is beyond the scope of this article, a few of the protocol features are particularly important in the context of the Minor Injury Cap. First, the protocols require a "minor injury" diagnosis to be made with reference to specific

Section l(j) of the MIR, ibid., states:

"serious impairment", in respect of a claimant, means an impairment of a physical or cognitive function

(i) that results in a substantial inability to perform the

(A) essential tasks of the claimant's regular employment, occupation or profession, despite reasonable efforts to accommodate the claimant's impairment and the claimant's reasonable efforts to use the accommodation to allow the claimant to continue the claimant's employment, occupation or profession,

(B) essential tasks of the claimant's training or education in a program or course that the claimant was enrolled in or had been accepted for enrolment in at the time of the accident, despite reasonable efforts to accommodate the claimant's impaiment and the claimant's reasonable efforts to use the accommodation to allow the claimant to continue the claimant's training or education, or

(C) normal activities of the claimant's daily living.

(ii) that has been ongoing since the accident, and

(iii) that is expected not to improve substantially;

For a sprain, strain or WAD injury to be considered to have resulted in a serious impairment, the sprain, strain or WAD injury must be the primary factor contributing to the impairment.

See the DTR, supra note 2. Treatment in accordance with these protocols for up to 1$]$ or 22 weeks is paid for by substantially increased and pre-approved no-fault benefits. See the $A A I B A R$, supra note 2 , particularly s. 5(1) of that Regulation, which increases no-fault benefit limits to a maximum of $\$ 50,000$.

This presumption is established by s. $5(1)$ of the $M I R$, supra note 2, which reads: S(I) If

(a) a claimant sustains a sprain, strain or WAD injury as a result of an accident,

(b) the claimant is, without reasonable excuse, not diagnosed and treated in accordance with the diagnostic and treatment protocols established under the Diagnosic and Treatment Protocols Regulation, and

(c) the sprain, strain or WAD injury results in a serious impairment, the sprain, strain or WAD injury shall be considered to be a minor injury unless the claimant establishes that the sprain, strain or WAD injury would have resulted in a serious impairment even if the claimant had been diagnosed and treated in accordance with the protocols referred to in clause (b). 
publications, such as the International Classification of Diseases ${ }^{20}$ and the Scientific Monograph of the Quebec Task Force on Whiplash Associated Disorders: Redefining "Whiplash" and Its Management" and on the basis of "evidence-based practice."22 Second, the protocols establish treatment requirements that must be followed once a strain, sprain or WAD is diagnosed. Prominent amongst the treatment requirements in each case is education of the Minor Injury Claimant with respect to "the desirability of an early return to normal activities and to work" and "about self-care and the disadvantage of extended dependence on health care providers."23 Finally, if an injury is not "resolving appropriately" or is not resolved within 90 days from the accident, the Minor Injury Claimant may be referred to an Injury Management Consultant. ${ }^{24}$ To qualify as an Injury Management Consultant, the medical practitioner must use "evidence-based decision-making in his or her practice" and have demonstrated knowledge "with respect to the biopsychosocial model."2s The biopsychosocial model emphasizes the mind-body connection of illness and injury, suggesting that recovery from soft tissue injuries such as whiplash depends significantly on the mindset of the person who has the injury. ${ }^{26}$

\section{If, having applied the treatment protocols, a MVA Injury Claimant and the Tortfeasor} disagree as to whether the accident victim's injuries are minor, either party can call for an assessment of the injuries by a "certified examiner."27 Importantly, the examiner's opinion

See DTR, supra note 2, ss. 7, 11.

(Hagerstown, Md.: J.B. Loppencott Company, 1995), cited in DTR, ibid., s. 15.

See again for example DTR, ibid., ss. 7, 11, 15. Section 1(b) of the DTR, ibid, defines "evidence-based practice" as the "conscientious, explicit and judicious use of current best practice in making decisions about the care of a client, integrating individual clinical expertise with the best available external clinical evidence from systematic research."

See for example DTA, ibid., ss. 8, 12, 17, 20.

See DTA, ibid., ss. 24, 25. The Injury Management Consultant is a medical practitioner who has been registered as a Consultant by the Superintendent of Insurance. See DTA, ibid., s. 26.

DTA, ibid., s. 27.

For a further explanation of the biopsychosocial model in the context of motor vehicle accident induced soft tissue injuries, see the writings of Robert Ferrari, MD, FRCPC, a proponent of this model. For example: Robert Ferrari, "Whiplash is a social disorder - How so!" (2002) 44 B.C. Med. J. 307, online: The British Columbia Medical Association <www.bcmaorg/public/bc_medical_journal/BCMJ/ july_august_2002/whiplashsocialdisorder.asp>: Robert Ferrari, "Fibromyalgia and motor vehicle collisons - Oh, the pain!" (2002) 44 B.C. Med. J. 257, online: The British Columbia Medical Association <www.bcma.org/public/bc_medical_journal/BCMJ/june_2002/fibromyalgia.asp>. The biopsychosocial model is not universally accepted. For a critique, see for example: Robert W. Teasell, "The denial of chronic pain" (1997) 2:2 Pain Res. \& Mgmt. 89, online: Pulsus Group Inc. $<$ www.pulsus. com/Pain/02_02/teas_ed.htm>.

Section 8 of the MIR, supra note 2, sets out the following procedures for requesting and obtaining a certiffed examiner's opinion:

(1) If a claimant and a defendant disagree as to whether an injury sustained by the claimant as a result of an accident is or is nol a minor injury, either party may give notice to the other party in the prescribed form

(a) stating that the party giving notice desires to have a certified examiner assess the claimant for the purpose of giving an opinion as to whether the injury is or is not a minor injury, and

(b) specifying the name of the proposed certified examiner.

(2) If, on receipt of a notice under subsection (1), the other party

(a) accepts the certified examiner proposed under subsection (1)(b), that party must, within 14 days, so notify the party giving notice under subsection (1), or

(b) does not accept the certified examiner proposed under subsection (l)(b), that party must, within 14 days, so notify the party giving notice under subsection (1) and provide the name of a certified examiner that the party is willing to accept. 
is "prima facie evidence that the claimant's injury is or is not a minor injury, as the case may be." ${ }^{28}$ Further, if the MVA Injury Claimant unreasonably refuses to cooperate with the certified examiner, the injury is deemed to be a minor injury. ${ }^{29}$

\section{B. Impact of the Minor InJuRy CaP \& ASSOCIATEd Protocols}

The practical effect of the Minor Injury Cap is most easily explained in the context of Alberta's system of automobile accident injury recovery prior to the recent reforms. Before the reforms, a MVA Injury Claimant would obtain whatever medical treatment required or desired for his or her injury. A small portion of some medical treatments and expenses relating to the injury would be paid for by the MVA Injury Claimant's own automobile insurer. The MVA Injury Claimant would then sue the Tortfeasor for all remaining out of pocket expenses (including both past and future medical treatment and loss of income) and for compensation in the form of general damages for pain and suffering. In this lawsuit, the claimant would bear the burden of proving both the Torteasor's liability for the claimant's injuries and the quantification of the damages claimed. The claimant could choose the medical evidence to rely on in proving the extent of the injuries suffered and the quantification of damages. The claimant's entitlement to general damages was governed by

(3) If a party fails to provide notice under subsection (2), that party is considered to have accepted the certified examiner proposed under subsection (1)(b).

(4) If the parties cannot agree on a certified examiner to assess the claimant, either party may apply to the Superintendent in the prescribed form to select a certified examiner to assess the claimant.

(5) The Superintendent must, within 5 business days after receiving an applieation under subsection (4), select a certified examiner from the certified examiners register.

(6) The Superintendent may not select a certified examiner who was proposed by either party under this section.

(7) Notwithstanding anything in this section,

(a) neither the claimant nor the defendant may give notice under subsection (1) until at least 90 days have passed since the accident:

(b) only one assessment of the claimant in respect of the accident may be carried out under this section;

(c) a certified examiner is not eligible to assess a claimant under this section if the certified examiner

(i) has diagnosed or treated the claimant, or

(ii) has been consulted with respect to the diagnosis or treatment of the claimant

in respect of any injury arising from the accident.

Pursuant to s. 15 of the MIR, ibid, the Superintendent is required to "establish, maintain and administer a register of certified examiners," which is accessible to the public. Section 16 of the MIR, ibid, requires certified examiners to be medical doctors who have demonstrated knowledge of the philosophies set out in the Prolocol Regulation (DTR, supra note 2). According to $s .13$ of the MIR, ibid., the certified examiner's opinion is paid for by the party requesting the assessment.

MIR, ibid., s. 12.

:9 Section $10(3)$ of the MIR, ibid., requires the cooperation of the injured party as follows:

(3) If the claimant, without reasonable excuse,

(a) fails to attend an assessment for which notice has been given under section 9 or II(3),

(b) refuses to answer any relevant questions of the certified examiner about

(i) the claimant's medical condition or medical history, or

(ii) matters referred to in section I(j)(i) that relate to the claimant,

(c) fails to authorize the release of any relevant diagnostic, treatment or care information in respect of the claimant pursuant to subsection (2)(a), or

(d) in any other way obstructs the certified examiner's assessment,

the claimant's injury shall be considered to be a minor injury. 
a court's assessment of fair compensation for pain and suffering within the general damages range established by the Supreme Court of Canada. ${ }^{30}$

Under the Reform Package, a MVA Injury Claimant will have access to greater no fault benefits for medical and other expenses relating to his or her injuries. Based on the diagnostic and treatment protocols, the MVA Injury Claimant's injuries will be categorized as either minor or non-minor. While the MVA Injury Claimant can challenge a "minor injury" designation in court, to do so the MVA Injury Claimant must disprove the conclusions of the claims examiner. Where the "minor injury" designation is not challenged or is upheld by the court, the Minor Injury Claimant will be unable to successfully sue the Tortfeasor for general damages in excess of $\$ 4,000$, though full recovery of special damages (including lost income) will still be possible. In short, the Reform Package seeks to control the diagnosis and treatment of MVA Injury Claimants, to rapidly categorize the injury suffered as either minor or non-minor and to treat all Minor Injury Claimants alike by awarding only minimal damages for their pain and suffering.

\section{EquAl ACCESS to JUSTICE - SECTION 15 OF THE ChARTER}

\section{A. Setting the STAGe fOR a SeCtion 15 ANalysis}

The prevailing three-part test for determining whether a law violates the equality right guaranteed by s. 15 of the Charter was established by the Supreme Court of Canada in Law v. Canada (Minister of Employment and Immigration) ${ }^{31}$ (the Law Test). First, the challenged legislation must draw a distinction between two or more groups. Second, the distinction must be based on one of the grounds listed in s. 15 or on analogous grounds. Finally, the distinction must be one that would cause a reasonable person in the position of the claimant to feel less worthy as a human being or to feel that his or her human dignity is demeaned by the legislation at issue. With regard to this final criteria, the Supreme Court identified four contextual factors which may be considered: (a) the existence of pre-existing disadvantage

The Supreme Court's treatment of general damages was accuralely summarized by the Ontario Court of Justice (General Division) in Hernandez v. Palmer (1992), I5 C.C.L.I. (2d) 187 at para. 18 [Hernandez] as follows:

In the 1978 trilogy, which included Teno v. Arnold, [1978] 2 S.C.R. 287, non-pecuniary general damages were capped at $\$ 100,000$. This was varied in 1981 by l.indal v. Lindal, $[1981] 2$ S.C.R. 629 in that the cap on non-pecuniary general damages was increased by the rate of inflation.... Other injuries must, of course, be scaled down by considering their severity vis a vis the maxinum permitted.

[1999] I S.C.R. 497 [Law]. The Law Test was described in Law by lacobucci J. at para. 39, as follows:

[A] court that is called upon to determine a discrimination claim under s. I5(1) should make the following three broad inquiries. First, does the impugned law (a) draw a formal distinction between the claimant and others on the basis of one or more personal characteristics, or (b) fail to take into account the claimant's already disadvantaged position within Canadian society resulting in substantively differential treatment between the claimant and others on the basis of one or more personal characteristics? If so, there is differential treatment for the purpose of s. 15(1). Second, was the claimant subject to differential treatmemt on the basis of one or more of the enumerated and analogous grounds? And third, does the diflierential treatment discriminate in a substantive sense, bringing into play the purpose of $5.15(1)$ of the $C$ harter in remedying such ills as prejudice, stereotyping, and historical disadvantage? The second and third inquiries are concerned with whether the differential treatment constilutes discrimination in the substantive sense intended by $s$. 15(1) [emphasis in original]. 
or prejudice directed toward the distinguished group; (b) the degree of correspondence between the basis for the differential treatment and the actual needs, characteristics and circumstances of the affected group; (c) the ameliorative purpose or effect of the legislation upon a more disadvantaged group; and (d) the nature of the interest affected by the law. ${ }^{32}$

The second and third parts of the Law Test reflect the Court's purposive approach to s. 15 and their recognition that differential treatment of groups of people is a necessary, but not a sufficient criteria, for finding a violation of the equality right. Virtually all laws draw distinctions between groups of people, but not every legislative distinction violates s. 15 . Only distinctions which are discriminatory, as defined by the latter two components of the Law Test, run afoul of s. 15.

Accordingly, the primary question involved in evaluating the Minor Injury Cap in the context of the Law Test is whether the Minor Injury Cap discriminates against Minor Injury Claimants. In analyzing this question I do not propose to dispute the regulatory definition of "minor injury" or to question the appropriateness of the diagnostic or treatment protocols linked to the Minor Injury Cap. Consideration of such issues is not necessitated by the Law Test and therefore lie outside of the scope of this article. ${ }^{33}$ Instead, in order to effectively apply the Law Test to the Minor Injury Cap, I will consider only the impact that the Minor Injury Cap has on a Minor Injury Claimant as defined by the regulations. In other words, I will analyze the effect of the Minor Injury Cap on the equality rights of an individual who has been properly classified as having suffered a minor injury given the criteria set out by regulation. Further, with respect to the comparator groups required for a s. 15 analysis, I will focus solely on the distinction that the Minor Injury Cap draws between Minor Injury Claimants and MVA Injury Claimants who suffer non-minor injuries. This is the bright dividing line created by the Minor Injury Cap and the line that is relevant to an equality analysis of the Minor Injury Cap. ${ }^{34}$

With these parameters in mind, my central argument is that, given the purposive interpretation of s. 15 and the criteria of substantive discrimination required by the Law Test, the Minor Injury Cap violates the Charter's guarantee of equality. In this regard, I suggest that a s. 15 analysis of the Minor Injury Cap is on all fours with the Supreme Court of Canada's reasoning in Nova Scotia (Workers' Compensation Board) v. Martin.3 Correspondingly, I reject the Ontario Court of Justice (General Division)'s dismissal of the s. 15 challenge in Hernandez ${ }^{36}$ as a reliable precedent for a 5.15 analysis of the Minor Injury

See Law, ibid. at para. 88. The four contextual factors are also discussed in detail elsewhere in the Law decision.

Again, the fact that $l$ am not addressing these elements of the Reform Package should not be taken as an endorsement or rejection of the merits of same.

Arguably, the Minor Injury Cap also creates a division between individuals who suffer Minor Injury in an automobile accident and those who suffer Minor Injury by other means. This division does not give rise to a s. 15 breach, however, because the categories in question are not based on the nature of disability but rather on the cause or source of disability. Causation of disability or injury is not a listed, or analogous, ground of discrimination under $\mathrm{s}$. 15 of the Charter and has accordingly been rejected by Canadian Courts as the basis for a s. 15 violation. For more on this point, see infra note 41 . [2003] 2 S.C.R. 504 [Marlin]. The unanimous judgment of the Court in Martin was written by Gonthier J.

Hernandez, supra note 30. 
Cap. While the legislative provisions at issue in Hernandez are certainly similar to those giving rise to the Minor Injury Cap, the s. 15 analysis in Hernandez is not consistent with prevailing Charter jurisprudence.

\section{B. THE MaRTIN CASE}

\section{FACTS AND FINDINGS IN MARTIN}

In Martin, the Supreme Court of Canada was asked to determine whether s. 10B of Nova Scotia's Workers ' Compensation $\mathrm{Act}^{37}$ and its associated regulations ${ }^{38}$ infringed $\mathrm{s}$. 15 of the Charter. The legislative provisions at issue prevented injured workers suffering chronic pain from receiving compensation under the regular workers' compensation system or under the tort system and limited benefits for such injuries to a four-week Functional Restoration Program. ${ }^{39}$ Applying the $L a w$ Test, the Court unanimously concluded that the equality right was infringed.

With respect to Law's requirement of differential treatment, the Court held that the challenged legislation distinguished between workers subject to the $W C A$ who suffered chronic pain and workers subject to the $W C A$ who did not have chronic pain. The Court found that, while the $W C A$ "prevents all injured workers from obtaining compensation in court, the Act also disentitles injured workers disabled by chronic pain to compensation and other benefits beyond the four-week period, as well as to an individual assessment of their condition and needs. " ${ }^{40}$ Accordingly, the first criteria of the Law Test was met. ${ }^{41}$

Next, the Supreme Court found that, because chronic pain is a physical condition giving rise to disability, the distinction drawn by the $W C A$ was based on the ground of "physical disability" listed in s. 15(1) of the Charfer. In reaching this conclusion, the Court held that legislation can be found to create a distinction on the basis of disability, even if the legislation as a whole applies only to the disabled:

S.N.S. $1994-95$, c. 10 [WCA].

Functional Restoration (M/ulli-Faceted Pain Services) Program Regulations, N.S. Reg. 57/1996. Martin, supra note 35 at paras. 67-68.

lbid. at para. 71.

Notably, the Court in Martin, ibid. at para. 72, rejected the argument that the $W C A$ also drew a relevant distinction between chronic pain sufferers who were subject to the WCA (i.e. those injured on the job) and chronic pain sufferers who had access to the tort system. In the words of the Court:

I do not believe that this comparison is appropriate. What distinguishes this group from the appellants is not mental or physical disability - both suffer from chronic pain. Rather, the only difference between them is that persons in the comparalor group are not subject to the Act and thus have access to the tort system, while the appellants have to rely on the workers' compensation system. In my view, the Court of Appeal correctly held that a s. 15(1) analysis based on this distinction would amount to a challenge to the entire workers' compensation system, a challenge which this Court unanimously rejected in Reference re Workers' Compensation Act, 1983 (N/d.). [1989] I S.C.R. 922. Moreover, such a comparison would also be inappropriate since compensation under the tort system normally requires the injured party to establish that his or her injury was caused by the negligence of another. Thus. even if the workers' compensation system did not exist, not all injured workers with chronic pain would have access to tort damages.

Similarly, in Hernandez, supra note 30, the Ontario lower court rejected the division between automobile accident induced injury and injury by other means as being relevant to the $s$. 15 analysis. 
[1]n the present case, it is no answer to say that all workers subject to the scheme are disabled. The second slep of the Law test does not ask whether the claimant and members of the comparalor group possess a certain characteristic. Rather, the inquiry is whether the basis of the challenged differential treatment is an enumerated or analogous ground. The distinction between the claimants and the comparator group was made on the basis of the claimants' chronic pain disability, i.e., on the basis of disability. The fact that injured workers without chronic pain have their own disability too is irrelevant. Distinguishing injured workers with chronic pain from those without is still a disability-based distinction. ${ }^{42}$

Moreover, the Court reiterated its previous finding that " $a$ legislative distinction between temporary and permanent disability was based on the enumerated ground of 'physical disability"'43 and noted that "the analysis of distinctions drawn between various disabilities allows the courts to take into account a fundamental and distinctive characteristic of disabilities when compared to other enumerated grounds of discrimination: their virtually infinite variety and the widely divergent needs, characteristics and circumstances of persons affected by them." ${ }^{44}$ The Court also pointed out that the fact that a law is responsive to the needs of people with one type of disability does not impact on the question of whether the law is unresponsive to the needs of people with another type of disability: "If a government building is not accessible to persons using wheelchairs, it will be no answer to a claim of discrimination to point out a TTY (teletypewriter) telephone for the hearing impaired has been installed in the lobby." 45

In applying the third criteria of the Law Test, the Court in Martin emphasized the contextual nature of this question. The Court reiterated its finding in $L a w$ that the purpose of $s .15$ is

to prevent the violation of essential human dignity and freedom through the imposition of disadvantage, stereotyping, or political or social prejudice, and to promote a society in which all persons enjoy equal recognition at law as human beings or as members of Canadian society, equally capable and equally deserving of concern, respect and consideration. ${ }^{46}$

The Court also cited Law for the notion that, in the context of s. 15 of the Charter, human dignity "is harmed by unfair treatment premised upon personal traits or circumstances which do not relate to individual needs, capacities, or merits ... Human dignity is harmed when individuals and groups are marginalized, ignored, or devalued." ${ }^{\text {(17 }}$

Martin, ibid. at para 80

Ibid. at para. 79. Notably, the Court was referring to Granovshy v. Canada (Minister of Employmemt and Immigration], [2000] I S.C.R. 703 [Granovsky], wherein the Court found that the Canada Pension Plan's distinction for benefits purposes between people suffering temporary disability and those suffering permanent disability was a distinction drawn on the basis of disability for the purposes $s .15$ of the Charter. In that case, the s. 15 challenge failed on the third, "human dignity" element of the Lav Test. For further discussion of the Granovsky case in the context of the Minor Injury Cap, see Part III.D. of this article.

Ibid. at para. 85, citing Law, supra note 31 at para. 51 .

lbid. at para. 85, citing Law, supra note 31 at para. 53 . 
With these concepts in mind, the Court proceeded to apply the four contextual factors identified in Law. With respect to the question of pre-existing disadvantage or stereotype, the Court was faced with two contrary arguments. Counsel challenging the WCA provisions argued that chronic pain sufferers were the subject of a stereotypical assumption that their symptoms were not genuine but were attributable to psychosocial factors such as weakness of character or the promise of financial gain. ${ }^{48}$ On the other hand, counsel defending the $W C A$ provisions contended that chronic pain sufferers are on equal footing with all other injured workers "who are sometimes erroneously suspected of malingering," and that this common level of discrimination amongst the two types of injured workers negates the ability of chronic injury sufferers to claim historical disadvantage or stereotyping for the purposes of a s. 15 analysis.

The Court resolved this impasse by finding that injured workers suffering chronic pain did not necessarily have to establish that they were more historically disadvantaged than workers with other disabilities:

[W/hile a finding of relative disadvantage may in certain cases be helpful to the claimant, the absence of relative disadvantage should in my view be seen as neutral when, as is the case here, the claimants belong to a larger group - disabled persons - who have experienced historical disadvantage or slereotypes. ${ }^{30}$

Further, without deciding the matter, the Court found that sufficient evidence existed to conclude that chronic pain sufferers have suffered unique historical stereotyping, primarily by having their disability dismissed as being psychosomatic:

[T] he medical reports introduced as evidence oflen mention the inaccurate negative assumptions towards chronic pain sufferers widely held by employers, compensation oflicials and the medical profession ilself. They identify the correction of negative assumptions and altitudes of this kind as a significant step in improving the treatment of chronic pain. ${ }^{51}$

The Court also stated that, to the extent the medical evidence suggested that chronic pain syndrome is partly psychological, the $W C A$ provisions might also be characterized as drawing a distinction on the basis of mental disability. ${ }^{32}$ Viewing the impugned legislation in this context, the Court pointed out that it "has consistently recognized that persons with mental disabilities have suffered considerable historical disadvantage and stereotypes." \$3

Ibid. at para 86 wherein the Court summarized the Appellant's submissions as follows:

In other words, in the appellants' submission, the particular characteristics of chronic pain syndrome and related medical conditions, such as their persistence beyond the normal healing time for the underlying injury and the apparent lack of physical manifestations supporting the sufferet's complaint of continuing pain, have led to a common misconception, rising to the level of an invidious social stereolype, that persons affected by chronic pain do not suffer from a legitimate medical condition but are malingering, frequently with a view to financial benefits. or that their pain stems from weakness of character rather than from the injury itself.

Ibid. at paras. 88 .

lbid. at para. 90.

lbid.

lbid. 
In considering the second contextual factor, the Court concluded that the $W C A$ 's separate regime for chronic pain did not take into account the actual needs, capacity or circumstances of workers suffering from chronic pain in a manner respectful of their human dignity. The Court rejected the notion that the $W C A$ 's provision of early medical intervention through the Functional Restoration Program and its emphasis on returning the chronic pain sufferer to work responded to the actual needs and circumstances of chronic pain sufferers. In fact, the Court found that the decision to deny WCA benefits to chronic pain sufferers as a group reflected, rather than corrected, the prejudices historically inflicted on chronic pain sufferers. As stated by Gonthier J. for the Court:

I am unable to agree that the challenged provisions are sufficiently responsive to the needs and circumstances of chronic pain sufferers to satisfy the second contextual factor. Although the medical evidence before us does point to early intervention and return to work as the most promising treatment for chronic pain, it also recognizes that, in many cases, even this approach will fail. It is an unfortunate reality that, despite the best availabie treatment, clıronic pain frequently evolves into a permanent and debilitating condition. Yet, under the Act and the FRP Regulations, injured workers who develop such permanent impairment as a result of clironic pain may be left wilh nothing: no medical aid, no permanent impairment or income replacement benefits, and no capacity to earn a living on their own. This cannot be consistent with the purpose of the Act or with the essential human dignity of these workers. ${ }^{54}$

Also key to the Court's finding that the $W C A$ provision did not correspond to the actual needs of chronic pain sufferers was the fact that the $W C A$ did not provide for any individual assessment of the needs or conditions of chronic pain sufferers, but rather addressed the group as a whole. The Court held that the WCA's treatment of workers suffering chronic pain was

not based on an evaluation of their individual situations, but rather on the indefensible assumplion that their needs are identical. In effect, the Act stamps them all with the "chronic pain" label, deprives them of a personalized evaluation of their needs and circumstances, and restricts the benefits they can receive to a uniform and strictly limited program."s

As to the impact of this factor on the larger issue of deprivation of human dignity, the Court concluded as follows:

[T/he chronic pain regime under the [WCA] not only removes the appellants' ability to seck compensation in civil actions, but also excludes chronic pain sufferers from the protection available to other injured workers. It also ignores the real needs of workers who are permanently disabled by chronic pain by denying them any long-term benefits and by excluding them from the duty imposed upen employers to take back and accommodate injured workers. The Act thus sends a clear message that chronic pain sufferers are not equally valued and deserving of respect as members of Canadian society. ${ }^{56}$

With respect to Law's third contextual factor, the Court absolutely rejected the suggestion that the goal of the $W C A$ 's differential treatment of chronic pain sufferers was to improve the 
circumstances of another, more disadvantaged group. While noting that some workers might be more severely disabled than those suffering from chronic pain, the Court held that "there is no evidence that the comparator group as a class is in a more disadvantaged position than the group of injured workers suffering from chronic pain." challenged provisions of the $W C A$ to be "inconsistent with the ameliorative purpose of the Act." $\$ 8$

Finally, in considering the nature of the interest affected, the Court held that an economic deprivation can have both a direct and an indirect negative effect on human dignity:

In many circumstances, economic deprivation itself may lead to a loss of dignity. In other cases, it may be symplomatic of widely held negative attitudes towards the claimants and thus reinforce the assqult on their dignity. ${ }^{59}$

The Court found that the $W C A$ provisions that denied financial benefits impacted on three important interests that related to the human dignity of injured workers suffering chronic pain. First, the loss of financial benefits may impact on dignity because some workers suffering chronic pain may have no other means of financial support. ${ }^{60}$ Second, human dignity was negatively impacted by the fact that chronic pain sufferers were also denied an opportunity to access the compensation scheme available to other injured workers in the province, on the basis of the nature of their disability. ${ }^{6}$ Finally, the $W C A$ deprived injured workers with chronic pain of "ameliorative benefits, such as vocational rehabilitation services, medical aid and a right to accommodation, which would clearly assist them in preserving and improving their dignity by returning to work when possible."

In short, the Court found the nature of the interest affected by the challenged WCA provisions to be broader than the pure economic impact of the provisions. Indeed, the critical interest affected was the public's negative perception of chronic injury sufferers - a perception that the Court found to be exacerbated, rather than alleviated, by the legislative provisions:

Thus, far from dispelling the negative assumplions about chronic pain sufferers, the scheme actually reinforces them by sending the message that this condition is not "real", in the sense that it does not warrant individual assessment or adequate compensation. Chronic pain sufferers are thus deprived of recognition of the reality of their pain and impairment, as well as of a chance to establish their eligibility for benefits on an cqual fouting with others. This message clearly indicates that, in the Nova Scotia legislature's eyes. chronic pain suffierers are not equally valued as members of Canadian society."

Ibid. at para. 102 .

lbid.

lbid. at para. 103.

Accordingly, the Coun found that "it cannol be said that the loss of financial benefits liere is a trivial matter" (ibid. at para. 104).

lbid.

lbid.

lbid. at para. 105. 


\section{ThE APPLICATION OF MARTIN TO THE MINOR INJURY CAP}

At every juncture of the Law Test, a s. 15 evaluation of the Minor Injury Cap mirrors the analysis and the findings of the Supreme Court in Martin. As with the chronic pain limitation at issue in Martin, the Minor Injury Cap clearly draws a distinction between two groups of physically injured people and thereby meets the first element of the Law Test. In the case of the Minor Injury Cap, the distinction is drawn between Minor Injury Claimants and MVA Injury Claimants with non-minor injuries. Minor Injury Claimants are disadvantaged because the Minor Injury Cap restricts their entitlement to compensation for general damages. A Minor Injury Claimant receives a maximum compensation of $\$ 4,000$ in general damages for pain and suffering regardless of his or her individual circumstances. MVA Injury Claimants with non-minor injuries are not similarly restricted by the Minor Injury Cap. Instead, those with non-minor injuries remain entitled to receive full compensation for pain and suffering, as determined by an individualized assessment of each claimant's situation. Moreover, MVA Injury Claimants with non-minor injuries are given the opportunity for a court to individually assess their general damage entitlement. Minor Injury Claimants are effectively denied this opportunity for any general damages in excess of $\$ 4,000 .^{64}$ Accordingly, as in Martin, the Minor Injury Cap treats one group of injured people differently than another in terms of the amount of, and the opportunity for, individualized compensation for a particular injury.

Also, like the $W C A$ provision at issue in Martin, the legislative distinction created by the Minor Injury Cap is based on physical disability. Indeed, the very purpose of the Minor Injury Cap is to categorize MVA Injury Claimants according to the extent and nature of their injuries so as to limit the compensation available to those who suffer minor injury. The Supreme Court's findings in Martin that legislative distinctions relating to the nature, severity and duration of personal injury constitute distinctions based on physical disability and that distinguishing one injured or disabled group from another remains a distinction based on physical disability clearly apply to the divisions created by the Minor Injury Cap. Accordingly, the Minor Injury Cap satisfies the second element of the Law Test by drawing a distinction between two groups on the basis of a ground listed in s. 15 of the Charter.

Finally, the Minor Injury Cap likely fulfills the third requirement of the Law Test because a reasonable individual subject to the Minor Injury Cap would feel that his or her human dignity was being called into question by the $\$ 4,000$ general damage limit, just as the Court in Martin found that a reasonable individual suffering chronic pain would feel that his or her human dignity was demeaned by the absence of Workers Compensation Benefits relating to that disability. As was the case with chronic pain victims in Martin, the Minor Injury Cap essentially tells Minor Injury Claimants that, because of the nature of their physical disability, they are not entitled to the same benefit of the law as MVA Injury Claimants suffering nonminor injuries. Whereas people in the latter category are entitled to claim full compensation for pain and suffering, Minor Injury Claimants are limited to $\$ 4,000$ in general damages even 
if the true value of their pain and suffering exceeds this amount. It seems obvious that, absent the Minor Injury Cap, the general damages that a court might award for pain and suffering based on an individualized assessment of a Minor Injury Claimant's circumstances could easily exceed $\$ 4,000$. If this were not the case, the Minor Injury Cap would not serve any purpose. ${ }^{65}$ Moreover, as noted above, while MVA Injury Claimants with non-minor injuries have the opportunity to have the value of their general damages individually assessed by the court, Minor Injury Claimants are effectively denied this opportunity. The message that the Minor Injury Cap accordingly sends to Minor Injury Claimants is that their general damage claim merits little more than nuisance value - not because of an assessment of their pain and suffering as individuals but because their injury puts them in a particular category of MVA Injury Claimants.

Critical to a full appreciation of the link between the distinction created by the Minor Injury Cap and the notion of human dignity, is the fact that general damages reflect compensation for pain and suffering. To cap general damages with respect to particular types of injuries is to suggest that the pain and suffering associated with those injuries can be predetermined without consideration of each individual's circumstance. This approach suggests that Minor Injury Claimants do not incur pain and suffering which is real or significant or worthy of the legal protections and procedures associated with every other motor velicle accident related injury. Accordingly, as in Martin, the legislative provision perpetuates and reinforces negative stereotypes against a specific class of disabled people.

The Minor Injury Cap's negative impact on the human dignity of Minor Injury Claimants is further demonstrated via the contextual factors identified in Law. Again, the application of these contextual factors to the Minor Injury Cap largely reflects the analysis employed by the Supreme Court in Martin. First, like the chronic pain sufferers in Martin, Minor Injury Claimants are arguably subject to negative stereotyping arising from the idea that soft tissue injuries are largely psychosomatic. ${ }^{60}$ Worse yet, because soft tissue injuries are not necessarily verifiable by medical testing, Minor Injury Claimants are often presumed to be fraudulent in their injury claims. ${ }^{67}$ As was the case with the WCA in Martin, the Minor Injury

For examples of some general damage awards provided by Alberta courts to MVA Claimants suffering mild whiplash injuries prior to the Reform Package, sec: "2003 Insurance law Year in Review: Review of Alberta Quantum Assessments," online: MeLenıan Ross LL.P <iwww.mross.com/infogluebeliver LiveMross/digital_Assets/361_1233_1095351234098_2003\%20Insurance\%20Year\%20Review\%20s lides.pdß: and Alan S. Rudakofr, Kevin E. Barr \& llagar Niv-Renern, "A Decade of Whiplash Decisions in Alherta, 1992-2002," online: Macleod Dixon LI.P < www macleoddixon.com/contenu/files/ A_decade_of_Wlaplash_Decisions_in_Alberta.pdr>.

Indeed, the biopsychosocial modal that the Reform Package relies on is arguably based on this negative presumption (see supra note 26). Further, by emplasizing, as primary treatment, the education of Minor Injury Claimants about the benefits and desirability of "an early return to normal activities and work" and the "disadvantage of extended dependence on health care providers" (DTA, supra note 23), the Treatment Protocols underlying the Minor Injury Cap rellect the idea that minor injuries (as defined) are not genuine pliysical conditions.

See e.g. "Insurance Fraud l.cgislation," online: Alberta Molor Association <iwww.ama.ab.cal advocacy/insurance Fraud.pdis, which states:

The Insurance Bureau of Cantala (IBC) data indicate that 70 to 75 per cent of automobile injury

claims in Alberta are for soft tissue injuries or are whiplash-related. Recent studies suggest that

25 per cent of these claims are fraudulent. In these claims, injured parties are:

1) Significantly exaggerating the degree of pain and/or recovery time;

2) Claiming for injuries that do not exist or for medical conditions which pre-date the collision: 
Cap perpetuates these stereotypes by suggesting that individualized analysis is not required to determine the appropriate amount of compensation payable to each Minor Injury Claimant.

Second, the Minor Injury Cap does not take into account the actual needs, capacity or circumstances of Minor Injury Claimants. The Minor Injury Cap prevents the need for individualized general damages assessments for Minor Injury Claimants. Individualized assessment of pain and suffering, however, is precisely what each Minor Injury Claimant needs in order to be justly compensated for his or her pain and suffering. Further, the disparity between the actual needs and circumstances of Minor Injury Claimants and the distinction created by the Minor Injury Cap is not rectified by the increased no-fault (Section B) benefits available to Minor Injury Claimants under the Reform Package. These increased benefits provide funding for medical treatment and other out-of-pocket expenses (that is, special damages) associated with a Minor Injury. The benefits do not stand in the place of the compensatory damages for pain and suffering that are restricted by the Minor Injury Cap. As was the case in Martin, the benefits remaining under the legislation simply do not address the same need as the benefits removed.

Moreover, as with the WCA in Martin, the Minor Injury Cap fails to address the individual circumstances of each victim in a motor vehicle accident and instead treats all Minor Injury Claimants as a group. Accordingly, as in Martin, the legislation is "not based on an evaluation of their individual situations, but rather on the indefensible assumption that their needs are identical. ${ }^{108}$ Since the objective of the Minor Injury Cap is to forestall the need for an individualized general damages assessment of Minor Injury Claimants, the Minor Injury Cap by definition fails to respond to the unique circumstances of each Minor Injury Claimant.

Third, the Minor Injury Cap's differential treatment of Minor Injury Claimants is not designed to ameliorate the condition of a more disadvantaged group. Certainly the comparator group of MVA Injury Claimants who suffer non-minor injuries is not subject to any disadvantage that is alleviated by the Minor Injury Cap. Again, the situation is akin to that in Martin, wherein the Supreme Court held that no ameliorative purpose was served by a Workers' Compensation scheme that denied benefits to workers suffering from a particular type of disability. Indeed, in Martin the ameliorative purpose argument was stronger than in the present case because the $W C A$ legislation at issue in Martin concerned the allocation of government resources amongst injured workers. The Minor Injury Cap is unrelated to the distribution of limited government resources because it operates in the context of a privatized (albeit regulated), fault-based, automobile insurance system. In both situations, however, while the legislation may have economic benefits for society at large, the limiting provision does not directly better the position of the comparator group.

or

3) Claiming for expenses or loss of income that were not incurred.

Martin, supra note 35 at para. 99. Of course, the wording of the Minor Injury Cap (sce supra note II) indicates that an individualized assessment of general damages up to the $\$ 4,000$ cap is possible. This minor concession to a personalized assessment does not effectively address the problem, however, since the relevant claimant for a s. 15 analysis of the Minor Injury Cap is the claimant whose general damages would otherwise exceed $\$ 4,000$ but for the statutorily imposed limit. 
Fourth, the nature of the interest affected by the Minor Injury Cap is not trivial. For a Minor Injury Claimant, the difference between receiving a $\$ 4,000$ general damages award or an award that accurately reflects the degree of his or her pain and suffering may be financially significant to the individual involved. Even a difference of a few thousand dollars, though statistically insignificant, may make a huge difference in the financial circumstances of a particular Minor Injury Claimant. More importantly, however, as in Martin, the interest affected by the Minor Injury Cap is not purely financial. Indeed, a wider aspect of human dignity question is implicated by the Minor Injury Claimant's loss of opportunity to obtain an individualized assessment of due compensation. The Supreme Court's words in Martin with regard to chronic pain sufferers, apply equally to Minor Injury Claimants: "Ihus, far from dispelling the negative assumptions about [Minor Injury Claimants], the scheme actually reinforces them by sending the message that this condition is not 'real', in the sense that it does not warrant individual assessment or adequate compensation."

Of course, it may be argued that the $W C A$ in Martin had a greater impact on human dignity than the Minor Injury Cap because of the amount of benefits restricted by the respective legislative provisions. The $W C A$ provision prevented chronic pain sufferers from accessing any of the benefits available to other injured workers. By contrast, the Minor Injury Cap only restricts one of several heads of damage that might be pursued by a Minor Injury Claimant. Here again, however, the relationship of general damages to individual pain and suffering must be taken into account. Human dignity is enhanced by the law's recognition, validation and compensation of individual pain and suffering; human dignity is correspondingly reduced by the law's suggestion that particular injuries do not necessitate such recognition, validation or compensation.

It may also be argued that the Minor Injury Cap does not affect as serious an interest as the legislation at issue in Martin because of the nature of the injury involved. That is, the Minor Injury Cap by definition applies only to people who do not incur long-term injuries, where the legislation at issue in Martin affected people suffering from chronic pain (a longterm condition). While I do not contest the fact that the legislation in Martin dealt with a different, and more serious, physical disability, the Minor Injury Cap still constitutes a legislative distinction based on physical disability. The relevant interest affected is not the severity of the injury but the ability to pursue tort compensation that is commensurate with the injury. To argue otherwise is to perpetuate the stereotype or the discriminatory view that people who suffer less severe injuries are less worthy of access to justice.

Accordingly, based on the requirements of the Law Test and following the analysis provided by the Supreme Court of Canada in Martin, the Minor Injury Cap clearly infringes on the equality right guaranteed by s. 15 of the Charter. This conclusion, however, runs contrary to the Ontario lower court finding in Hernandez. ${ }^{70}$ I will therefore next consider the s. 15 analysis offered in that case.

Martin, ibid. at para. 105. To cmplasize my point that the Supreme Court's conclusions are applicable to an analysis of the Minor Injury Cap, I have replaced the words "chronic pain sufferers" will, "Minor Injury Claimants." The notion that "generalized" treatment of people suffering loss or injury oflends s. 15 of the Charter was also recently expressed by the Alberta Cuurt of Appeal in Ferraimolo v. Olson, 2004 ABCA 281 at para. 102 [Ferrainolo]. 


\section{TIIE HERNANDEZ CASE}

\section{FACTS AND FINDINGS}

In Hernandez, the General Division of the Ontario Court considered a s. 15 Charter challenge to 5.266 of Ontario's Insurance Act. ${ }^{71}$ This statutory provision created a partial nofault automobile insurance system by significantly restricting the ability of MVA Injury Claimants to sue the Tortfeasor for compensation. In particular, the right to sue was restricted to claimants whose accident injuries constituted "permanent serious disfigurement" or "permanent serious impairment of an important bodily function caused by continuing injury which is physical in nature." ${ }^{72}$ When viewed in combination with other Insurance Act amendments that increased the amount of no-fault benefits available to motor vehicle accident victims, the effect of s. 266 of the Insurance Act was to exchange "the unlimited ability to sue in tort" for "substantially increased no-fault benefits." 73

The judgment in Hernandez was issued on 7 December 1992, several years before the Supreme Court of Canada's ruling in Law. Accordingly, at the time Hernandez was decided, s. Is Charter analysis was governed by the test set out by the Supreme Court of Canada in Andrews v. Law Society of British Columbia ${ }^{74}$ (the Andrews Test). The tri-partite Andrews Test states that a law violates $s .15$ if it draws a distinction between two or more groups, if the distinction is based on a ground listed in $\mathbf{s .} 15$ or on grounds analogous thereto and if the legislative distinction results in an advantage or disadvantage to the defined groups. ${ }^{75}$ While

R.S.O. 1990, c. 1-8. Section 260 was Ontario's first attempt at a partial no-fault system. The provision challenged in /lernandez, ibid., read as follows:

(1) In respect of loss or damage arising directly or indirectly from the use or operation, after the

21 st day of June, 1990, of ant automobile and despite any other $A c t$, none of the owner of an automobile, the occupants of an automobile or any person present at the incident are liable in an action in Ontario for loss or damage from bodily injury arising from such use or operation in Canada, the United States of America or any other jurisdiction designated in the No-Fault Benefits Schedule involving the automobile unless, as a result of such use or operation, the injured person has died or has sustained,

(a) permanent serious disfigurement; or

(b) permanent serious impairment of an important bodily function caused by continuing injury which is physical in nature.

Ontario has since implemented wo other no-fault systems that operate under slightly different principles than the system at issue in Hernandez. For a summary of each ofOntario's no-fault schemes, see Craig Brown \& Ramon V. Andal, Insurance Law in Canada, looseleaf (Scarborough: Carswell. 1999) at 17-16-17-18.

lbid., s. 266(1).

Hernandez, supra nole 30 at para. 45.

[1989] I S.C.R. I43 [Andrew's].

The Court in Hernandez, supra note 30 at para. 167, summarized the Andrews Test by citing the words of Lamer C.J.C. in R. v. Siwain, [1991] ] S.C.R. 933 at 992 as follows:

The court must first determine whether the claimant has shown that one of the four basic equality rights has been denied (i.c., equality before the law, equality under the law, equal protection of the law and equal benefit of the law). This inquiry will focus largely on whether the law has drawn a distinetion (intentionally or otherwise) between the claimant and others, bosed on personal characteristics. Next, the court must determine whether the denial can be said to result in "discrimination." This second inquiry will focus largely on whelher the differential treatment has the effect of imposing a burden, obligation or disadvantage not imposed upon others or of withholding or limiting access to opportunities, benefits and advantages available to others. Furthermore, in determining whether the claimant's s. 15(1) rights have been infringed, the court 
this test offered a purposive approach to s. 15, the Andrews Test did not include the objective/subjective analysis of the legislative impact on human dignity that figures so prominently in the present day Law Test.

Relying on the Andrews Test, the Court in Hernandez held that Ontario's no-fault threshold was not discriminatory under s. 15 of the Charter. The Court found that s. 266 of the Insurance $A c /$ did create an inequality between automobile accident victims who suffered bodily injury sufficiently serious to meet the statutory threshold and automobile accident victims whose injuries fell below this threshold. ${ }^{76}$ The Court also found that people falling below the statutory threshold were "affected disproportionately in a negative way" because they were "precluded from the recovery permitted those who survive the threshold. This limits their access to benefits and advantages available to the threshold group." the Court refused to characterize the injury-based distinction as a distinction based on the grounds of physical or mental disability listed in s. 15(1) of the Charter or on any analogous ground. In the words of the Court:

[S/ome victims will be able to litigate because their injuries survive the threshold. What remains is a differentiation premised upon the severity and nature of the injuries sustained. The distinction created by the impugned legislation is not, in my view, related to the personal characteristics of the victim and therefore is not mental or physical disability as enumerated in s. $15(1)$ or a ground analogous thereto. ${ }^{78}$

In support of its refusal to find that a distinction based on the degree of injury suffered in an automobile accident constituted a listed or analogous ground of discrimination, the Court noted that injured individuals who fell below the legislative threshold were "not associated with a group which has been historically disadvantaged from a social, political or legal context nor have they been subject to stigmatization or stereotyping"79 and did "not constitute a traditionally afflicted group of the type that s. $15(1)$ is meant to protect." The Court found that the only disadvantage suffered by people falling below the legislative threshold was the distinction created by the legislation itself. In the eyes of the Court, this disadvantage was offset by increased no-fault benefits:

Here the plaintiff is advancing his plysical integrity. and that of his group vis à vis those who pass the threshold but there is no disadvantage apart from the distinction being challenged. Fach group, above and below the threshold is entitled to receipt of all benefits available. The difference is the rights to the additional recovery preserved in the right to successfully sue. The claallenge is prenised upon the comparative capacity arising from the accident and injuries and is, as such, not capable, in the circumstances of being a successful challenge since each group both above and below the threshold is entitled to receipt of all benefits available.

must consider whether the personal characteristic in question falls within the grounds enumerated in the section or within an analogous ground, so as to ensure that the claim fits within the overall purpose of s. 15 - namely. to remedy or prevent discrimination against groups subject to stereotyping. historical disadvantage and political and social prejudice in Canadian society.

Hernandes, ibid. at para. 203. where the Court stated: "It would appear to me... that the Plaintiff is denied equality under the law or the equal benefit of the law when one considers the extinguishment of their right to recover when related to those who have survived the threshold created by s. $266(1)$." Ibid. at paras. 204-205

lbid. at para. 207.

Ibid. at para. 208.

lbid. at para. 210. 
Any loss associated with the removal of the right of action for those below the threshold is offset by the overall benefit provided under the Act. The impugned legislation does not deprive individuals of rights but, in fact, exchanges their right of action with a right to comprehensive no-fault benefits. As such, in my view, it does not create discriminatory inequality within the meaning of $s .15(1)^{81}$

The Court also found that, because the legislation "merely limited the right to sue in tort, not abolished it, while substantially enhancing no-fault benefits as a concomitant," s. 266 of the Insurance Act did not give rise to any "stigmatizing judgments" or the imposition of "onerous treatment" upon injured parties who did not meet the statutory threshold. ${ }^{82}$

Finally, the Court in Hernandez called upon s. 15(2) of the Charter to support its dismissal of the equality challenge. Section 15(2) states that the equality rights set out in s. 15(1) of the Charter do not "preclude any law, program or activity that has as its object the amelioration of conditions of disadvantaged individuals or groups including those that are disadvantaged because of ... physical disability." ${ }^{83}$ The Court held that, to the extent that the threshold created by s. 266 of the Insurance Act was based on degree of physical disability, it fell within the confines of s. 15(2) of the Charter because the effect of the legislation was "to give an additional benefit to persons with permanent serious impairment or disfigurement in order to accommodate the severity of their injury or loss." $\$ 4$

\section{THE APPLICATION OF HERNANDEZ TO THE MINOR INJURY CAP}

The temptation to use Hernandez as a precedent for finding that the Minor Injury Cap does not violate s. 15(1) of the Charter is obvious. The legislative provision at issue in Hernandez is akin to the Minor Injury Cap in that both laws relate to a larger provincial automobile insurance scheme, both laws limit the ability of some MVA Injury Claimants from using tort law to recover compensation for their losses, and both laws draw this restriction on the basis of the nature and extent of the injury suffered by a MVA Injury Claimant. Indeed, the Minor Injury Cap is arguably less restrictive than the limitation created by the Ontario provision at issue in Hernandez because the Minor Injury Cap only restricts the ability to recover general damages while s. 266 of Ontario's Insurance $A c t$ prohibited any fault-based recovery.

Despite the similarities in the relevant facts, however, as a matter of law the Court ruling in Hernandez cannot properly be used as a precedent for an equality analysis of the Minor Injury Cap. First and most obviously, the Andrews Test relied upon in Hernandez has since been significantly modified by the Supreme Court of Canada's Law Test. The additional elements of the Law Test, including in particular the human dignity question and the contextual factors, must be applied to an evaluation of the Minor Injury Cap. Second, many of the conclusions reached by the Court in Hernandez with regard to the nature of "listed or analogous grounds" have since been rejected on the basis of the Law Test. As noted in my review of Martin, while the source of an injury may not constitute a listed or analogous ground, the courts have found that the nature and extent of injury itself does constitute a 
physical or mental disability within the meaning of s. 15. Further, while the Court's reasoning in Hernandez suggests that an analogous ground necessarily refers to a group of people who have suffered prejudice that is distinct from the comparator group, the Supreme Court of Canada has since found that a s. 15 analysis does not imply a "race to the bottom"" as among the comparator groups. ${ }^{85}$ In other words, the allegedly discriminated group does not need to establish greater historical discrimination than the comparator group in order for the court to find a s. 15 violation. Third, the Court's argument that any disadvantage imposed by the limitation on litigation is offset by increased no-fault benefits misunderstands the nature of the benefits involved. As noted earlier, no-fault benefits relate to pecuniary losses associated with injuries and not to non-pecuniary damages for pain and suffering. Accordingly, the legislation at issue in Hernandez did not compensate equally for the ability to sue for general damages, just as the increased no-fault benefits in Alberta's Reform Package do not take the place of the Minor Injury Cap's limitation of general damages. Finally, the Court's application of s. 15(2) in Hernandez is inconsistent with the Court's interpretation of s. 15(1). If the type and extent of bodily injury does not fall within a listed or analogous ground under s. 15(1), then how can this same distinction support ameliorative legislation within the context of s. 15(2)? Moreover, as noted earlier, the Minor Injury Cap does not directly better the position of MVA Injury Claimants with non-minor injuries.

\section{SOME FURTHER THOUGHTS ON THE EQUALITY ANALYSIS}

In defending the Minor Injury Cap, the Government of Alberta emphasizes the fact that a MVA Injury Claimant can challenge a "minor injury" designation in court" and that Minor Injury Claimants can still claim full compensation for special damages, including medical expenses and loss of income. ${ }^{87}$ Neither of these components of the new insurance system, however, effectively address the s. 15 Charter problem. The key, again, is to focus on how the Minor Injury Cap affects a MVA Injury Claimant who, but for the Minor Injury Cap, would have recovered more than $\$ 4,000$ in compensation for pain and suffering.

The ability to challenge a minor injury designation only entitles a MVA Injury Claimant to an individualized assessment of the appropriate category for his or her general damages claim under the divisions created by the MIR. It does not provide for an individualized assessment of damages over $\$ 4,000$ unless the challenge is successful and the MVA Injury Claimant's loss is classified as a non-minor injury. Accordingly, the substantive inequality created by the Minor Injury Cap remains for MVA Injury Claimants whose injuries meet the regulatory definition of a minor injury. To say that it is "fair" for a MVA Injury Claimant to have his or her general damage compensation claim limited because his or her injury qualifies as a Minor Injury as defined by the regulations is tautological. The question is whether it is fair to limit an individual's ability to sue for full compensation for pain and suffering because of the nature of that individual's injury.

Similarly, the fact that a Minor Injury Claimant may seek other forms of compensation does not make the elimination of his or her ability to seek general damages any less discriminatory. General damages compensate for pain and suffering - a loss that is entirely 
different than out of pocket expenses, which are compensated by special damage awards. Indeed, this critical distinction formed the basis of the Alberta Court of Appeal's recent finding that s. 8(2)(c) of Alberta's Fatal Accident Act ${ }^{88}$ violated s. 15 of the Charter by restricting the ability of a child to sue for general damages for pain and suffering arising from the wrongful death of a parent:

[O|ne must not confuse the issue of non-pecuniary damages ... with pecuniary damages... The award for grief stands separate and apart from these other causes of action... What is in issue here is whicli children suffer grief on wrongful death of their parent, who is entitled to a cause of action for that loss - and who is not. 89

Likewise, in the context of the Minor Injury Cap, the critical question is: which injured parties are entitled to a cause of action for full compensation for pain and suffering - and which are not? Moreover, as further noted by Fraser C.J. of the Alberta Court of Appeal, it is the restriction on the ability of some individuals to pursue a cause of action that is available to others that raises the very notions of human dignity and self-worth, which are central to the $s .15$ analysis:

Preventing those in the claimant group frum sceking redress for wrongs done to them and attaching no legal recognition to the grief inflicted on them leads to a loss of self-worth and lack of empowerment. The interest affected by the differential treatment ... is qualitatively an important one. ${ }^{90}$

It should also be emphasized that the Charter's equality guarantee does not impair the government's ability to reform automobile insurance systems by creating categories or divisions upon which benefits or compensation will be provided. Section 15 of the Charter does not stand in the way of government designing legislative categories. In recognition of this point, Canadian courts have upheld the constitutionality of workers compensation schemes ${ }^{91}$ and insurance systems that differentiate between employed and self-employed claimants. ${ }^{92}$ Section 15 does, however, prohibit the creation of legislative categories that are substantively discriminatory. A primary problem with the Minor Injury Cap is that the categories created are based on the prohibited ground of physical (and arguably mental) disability.

Of course, according to the Law Test, not all legislative distinctions based on physical disability will necessarily violate s. 15. For example, in Granovsky, the Supreme Court found that s. 15 of the Charter was not violated by the Canada Pension Plan's failure to provide benefits to persons who were unable to pay premiums because of a temporary, as opposed to a permanent, disability. ${ }^{93}$ In Granovsky, however, the Court's rejection of the s. 15 challenge was based on its finding that the legislative distinction did not satisfy the human dignity component of the Law Test. Critical to the Court's ruling on the human dignity question was its characterization of the legislative purpose: namely, providing benefits to

R.S.A. 1980, c. F.5, as am. by the Fatal Accidents Amendment Act, S.A. 1994, c. 16.

Ferraiuolo, supra note 69 at para. 124. The finding and the overall reasoning in this case reinforces my view that the Minor Injury Cap violates s. 15 of the Charter according to the Law Test. lbid. at para. 134.

Reference re Workers ' Compensation Act. 1983 (NAd.), [1989] I S.C.R. 922.

W'ells v. Saskatchewan Government Insurance (1998), 169 Sask. R. 15I (Q.B.).

Supra note 43. 
individuals who are permanently disabled. ${ }^{94}$ On the basis of this characterization and the nature of the claimant's partial disability, the Court refused to find discrimination in any of the contextual factors raised by the Law Test. As noted earlier in this article, the Minor Injury Cap does not serve an ameliorative purpose and therefore the Granovsky analysis is distinguishable. ${ }^{95}$ More fundamentally, the Minor Injury Cap is not part of a government benefit program as was the case with the legislative provision at issue in Granovsky. Moreover, to the extent that the Minor Injury Cap is designed to protect society from rising insurance premiums by limiting access to the justice system, this objective alone may raise human dignity concerns. ${ }^{\%}$

In any event, if the objective of the Minor Injury Cap is to reduce litigation costs and insurance payouts for MVA Injury Claimants, the Alberta government could have achieved this objective without necessarily implicating the personal characteristics listed in s. 15(1) and the human dignity issue. ${ }^{97}$ For example, the government could have avoided categorizing MVA Injury Victims at all by reducing the common law cap on general damages for all MVA Injury Claimants or by moving to a full, no-fault automobile insurance system. Alternatively, the government could have based the recovery cap on the severity of the accident rather than the severity of the injury or subjected all insured owners and drivers to a mandatory deductible for general damage claims. ${ }^{98}$

\section{IMPLICATIONS OF THE EQUALITY ANALYSIS}

\section{A. SECTION 1 OF THE CHARTER}

A finding that the Minor Injury Cap infringes s. 15(1) of the Charter is a necessary, but insufficient, step in determining the constitutional validity of the Minor Injury Cap. If a court determined that the Minor Injury Cap violates the right to equality guaranteed by s. 15, (which, as I have argued, is an appropriate finding on the basis of Martin), it would then be necessary for the court to consider whether this infringement is justified under $s$. I of the

44 Ibid. at para. 48.

is Sec Part III.B.2 of this article.

*. See Ferraiwolo, supra note 69 at para. 116 wherein the Alberta Court of Appeal stated:

Depriving married or older children of legitimate damages for the grief they suffer on wrongful dealh of a parent in order to avoid any increase in insurance premiums for others constitutes, by itself, a discriminatory purpose. Moreover, it is, in its own right, an affront to human dignity. What this would mean to someone in Ferraiuolo's position is that the state considers the mere prospect of an increase in insurance premiums more worthy of consideration and more important than properly compensating children in the claimant group for the grief suffered by them on the wrongful death of their parent. This represents a classic example of self-interest trumping Charter values.

1 raise this issuc now to point out the difference between legislative distinctions that necessarily raise s. 15 issues and those that may not. The avaitability of other options for achieving a particular legislative purpose also figures prominently in determining whether a Charfer violation can be justified under s. I of the Charter. (Sec Part III.A. of this anticle).

It should be kept in mind, however, that even distinctions that do not directly raise s. $15(1)$ prohibited grounds of discrimination may still violate equality rights under the Charter on the basis of adverse effects. (See e.g. I'riend v. Alberta, [1998] I S.C.R. 493). Mandatory deductibles or damage awards based on the severity of the accident may have a disproportionately negative impact on Minor Injury Claimants. 
Charter. ${ }^{99}$ According to the well-established s. I test (the Oakes Test), ${ }^{100}$ the government would be required to demonstrate that the Minor Injury Cap serves a pressing and substantial objective, that the objective is rationally connected to the Minor Injury Cap, that the Minor Injury Cap infringes the equality right as little as possible within a range of reasonable alternatives and that the real and intended benefits of the Minor Injury Cap outweigh the Charter infringement (that is, that the Charter breach is proportional to the aims of the legislation).

In cases where a government offers very general objectives to justify Charter breaches, the court's application of the Oakes Test necessarily becomes a policy or values based decision and the judicial outcome accordingly becomes less predictable and frequently less definitive. This problem was specifically recognized by the Supreme Court in Martin, where the Court expressed its frustration in applying s. $I$ of the Charter given "the ambiguity of the respondents' submissions with respect to the legislative objective pursued by the challenged provisions." ${ }^{101}$ Generalized objectives of the sort that the Alberta government has offered to date in support of the Reform Package therefore may prove problematic in justifying the Minor Injury Cap under s. 1.

Because generalized objectives do not easily lend themselves to a principled application of s. I, I do not propose to consider in detail the outcome of a s. 1 analysis as it pertains to the Minor Injury Cap and the stated objectives. I will, however, offer some comments with respect to more specific objectives that may be put forward by the government. Again, the Martin case is instructive with respect to the approach the courts may take in applying s. 1 of the Charter to such objectives. Specific objectives of the Minor Injury Cap might include the cost-effective maintenance of the automobile insurance system, the need to prevent fraudulent claims and the need for early intervention in the medical treatment of Minor Injury Claimants. Comparable objectives did not satisfy the Oakes Test in Martin.

One objective raised with respect to the $W C A$ provision in Martin was the maintenance of the financial viability of the workers' compensation system. ${ }^{102}$ The Supreme Court noted that, while budgetary concerns ordinarily do not constitute pressing and substantial objectives under s. 1, this might be possible in certain circumstances. Still, the Supreme Court rejected this concern as being a pressing and substantial objective with respect to the $W C A$ provision at issue. The Court held that there was no evidence to establish that the chronic pain claims "in and of themselves placed sufficient strain upon the Accident Fund to threaten its viability, or that such claims significantly contributed to its present unfunded liability." ${ }^{03}$ The Court

Charter, supra note $5, \mathrm{~s}$. 1 provides that:

The Canadian Charter of Rights and Freedoms guarantees the rights and freedoms set out in it subject only to such reasonable limits prescribed by law as can be demonstrably justified in a free and democratic society.

R. v. Oakes, [1986] I S.C.R. 103 at 138-39. There has been some minor modification to this test over the years, but the general components remain in place.

Martin, supra note 35 at para. 108.

Ibid. at paras. 108-109.

lbid. at para. 109. 
similarly rejected the objective of achieving "a consistent legislative response" to particular claims as being pressing and substantial. ${ }^{104}$

This general approach was followed by the Alberta Court of Appeal in Ferraiuolo, wherein the Court rejected the avoidance of unacceptable insurance premium increases as the justification for a s. 15 breach. ${ }^{105}$ The Court of Appeal expressed serious doubt that the financial viability of a private industry could qualify as a pressing and substantial objective and, in any event, found that the government had failed to provide sufficient evidence to establish that the Charter breach was necessary to fulfill this objective:

\begin{abstract}
I now turn to consider whether avoiding unacceptable insurance premium increasts constitutes a pressing and subslantial objective. I have considerable reservations whether a limitation on a Charter right for some can be justified because of concerns about rising insurance premiums for olhers. The Supreme Court has made it clear that budgetary considerations by themselves cannot ordinarily be relied on as a free-standing pressing and substantial objective in their own right for purposes of s.l... It may be that this same reasoning applies all the more so when government seeks to rely on the fact that state action will have financial implications, not for the state itself, but for third parties, such as, for example, insurers and the insurance rates charged to the public generally. In these circumstances, the state action does not involve allocating scarce public resources amongst different disadvantaged groups but rather denying victims of a privale cause of action for compensation for injuries suffered by them.
\end{abstract}

A statutory scheme intended to protect the insurance premiums of those who are not injured, at the expense of those who are, potentially engages other Charter issues.

I assume, without deciding. that avoiding unacceptable insurance premium increases could constitute a pressing and substantial objective even though driving is a privilege and not a right. However, here, we have no evidence of the incremental cost of extending to all children the benefil of an award for damages for grief on wrongful death of a parent, much less any evidence that it would lead to "unacceptable" insurance premium increases. The obligation to lead evidence to support the breach of the $\mathrm{s}$. 15 equality guarantee rests squarely on Alberta. ${ }^{106}$

Obviously, the Alberta government would confront these obstacles again if it offered the protection of insurance premiums as an objective of the Minor Injury Cap.

Another objective raised in Martin was the need "to avoid potential fraudulent claims based on chronic pain, which would be difficult to detect under the normal compensation system, given that no objective findings are available to support chronic pain claims." ${ }^{107}$ The Supreme Court of Canada concluded that this was a pressing and substantial objective given "the general objective of the Act, as avoiding such claims ensures that the resources of the workers' compensation scheme are properly directed to workers who are genuinely unable to work by reason of a work-related accident." 108 The Court also found that the prohibition cannot be sufficiently pressing and substantial to override a Charter right" (ibid. at para. 110). 
of chronic pain benefits was rationally connected to prevention of fraud because "excluding all claims connected to chronic pain from the purview of the Act" would "virtually eliminate the possibility of fraudulent claims based on chronic pain." 109 Nevertheless, the Court found that the law failed to satisfy the $s$. 1 requirement of minimally impairing the equality right precisely because of the legislative link between possible fraud and the denial of chronic pain benefits:

The same reasoning, however. makes it patently obvious that the challenged provisions do not minimally impair the equality rights of chronic pain sufferets. On the contrary, one is tempted to say that they solve the potential problem of fraudulent claims by preemptively deeming all clironic pain claims to be fraudulent ... the provisions make no effort whatsoever to determine who is genuinely unable to work and who is abusing the system. ${ }^{110}$

Further, while recognizing that the minimal impairment test should not be failed simply because a judge "could imagine a less restrictive alternative," the Court found significance in the fact that other provinces had adopted less restrictive schemes."'

Finally, without deciding the importance of the objective nor the question of rational connection, the Court held that the WCA's objective of implementing "early medical intervention and return to work as the optimal treatment for chronic pain" did not satisfy the minimal impairment requirement. ${ }^{12}$ While the Court was satisfied on the basis of available evidence indicated that "early intervention and return to work together constitute the best available treatment for work-related chronic pain," the evidence did not indicate "that an automatic cut-off of benefits regardless of individual needs and circumstances is necessary to achieve the stated goal."113 Particularly significant to the Minor Injury Cap is the Court's "cautionary note" regarding this objective:

\footnotetext{
In my view, when a legislative provision that draws a distinction based on disability is found not to correspond to the needs and circumstances of the claimants to such a degree that it demeans their essential human dignity. the government will face a steep evidentiary burden if it chooses to allege that the provision is rationally connected to the objective of providing the best available treatment to such claimants. ${ }^{114}$
}

The Alberta government would presumably have to contend with this steep evidentiary burden in mounting a s. 1 defence of the Minor Injury Cap.

\section{B. Legislative Policy}

From a practical perspective, there is reason to doubt that Canadian courts will be called upon to determine whether the Minor Injury Cap is in breach of $s .15$ of the Charter. The cost of advancing such a challenge is prohibitive given the potential downside of being awarded only $\$ 4,000$ in general damages if the court upholds the legislation. Even if the court struck 
down the Minor Injury Cap, the cost of a challenge would also greatly exceed the value of any individualized damage award for a minor injury. Nevertheless, even if the $s .15$ analysis is never raised before the courts as a question of law, this analysis is relevant to the consider in the context of legislative policy and civil justice reform. The appropriateness of legislative policy choices is worthy of assessment even outside of a formal constitutional challenge before the courts.

As the above $\mathrm{s} .15$ analysis demonstrates, the Minor Injury Cap raises important questions about our notions of fair and genuine access to justice. The Minor Injury Cap and the associated Reform Package place serious obstacles in the way of MVA Injury Claimants seeking individualized compensation for mild soft tissue injuries. Moreover, these obstacles are based strictly on the nature of the claimant's injuries-an element that is clearly out of the control of the injured party. Albertans would readily concede that a country in which only certain classes of people can vote (for example, people within a given income bracket) is hardly a country in which the "right to vote" has any real meaning, despite the existence of a voting procedure. Similarly, a civil justice system that discourages or puts practically insurmountable obstacles in the way of some classes of people pursuing judicial remedies that are available to others cannot claim to provide equal access to the justice system.

In short, the Minor Injury Cap is a disappointing example of civil justice reform. The goal of civil justice reform should be one of inclusiveness and equality. Instead of discouraging or impeding meritorious claims, reform initiatives should be directed at the expeditious resolution of such claims in a manner that serves all meritorious claimants equally. As I have attempted to demonstrate through the s. 15 Charter analysis, the Minor Injury Cap by definition does not provide equal access to the justice system for all MVA Injury Claimants. On the contrary, the Minor Injury Cap uses Minor Injury Claimants as the scapegoat for the cost and efficiency problems associated with Alberta's automobile insurance system. "15

\section{CONCLUSION}

In this article I have argued that, on the basis of recent case law, the Minor Injury Cap violates the equality right guaranteed by s. 15 of the Charter. More specifically, I have attempted to demonstrate how the Supreme Court of Canada's analysis in Martin applies to the Minor Injury Cap and to show why the ruling in Hernandez is not a reliable precedent for an equality analysis of the Minor Injury Cap. Although my analysis is primarily a legal one, the considerations raised by this constitutional question also inform larger policy issues outside of the strict legal analysis. In particular, I conclude that the inequalities highlighted by the constitutional analysis in turn demonstrate that the Minor Injury Cap is, as a matter of policy, a poor civil justice reform initiative, which bears reconsideration even in the absence of a constitutional challenge. 